\title{
МЕЖДИСЦИПЛИНАРНЫЕ ИННОВАЦИОННЫЕ ПРОЕКТЫ В СФЕРЕ ВЫСШЕГО ОБРАЗОВАНИЯ: ОПЫТ КОЛЛАБОРАЦИИ В РАМКАХ НАУЧНО-ТЕХНОЛОГИЧЕСКОГО РАЗВИТИЯ"
}

\author{
(c) 2021 Щукина Татьяна Владимировна \\ доктор юридических наук, доцент, заведующая кафедрой прикладного права \\ МИРЭА - Российский технологический университет, Россия, Москва \\ (c) 2021 Забайкалов Андрей Павлович \\ доцент кафедры прикладного права, кандидат юридических наук, доцент \\ МИРЭА - Российский технологический университет, Россия, Москва \\ (c) 2021 Зуев Владимир Валерьевич \\ доцент кафедры цифровых и аддитивных технологий, кандидат технических наук, доцент \\ МИРЭА - Российский технологический университет, Россия, Москва \\ (c) 2021 Коновалов Николай Николаевич \\ доцент кафедры прикладного права, кандидат юридических наук, доцент \\ МИРЭА - Российский технологический университет, Россия, Москва \\ (C) 2021 Свечникова Вера Викторовна \\ старший преподаватель кафедры прикладного права \\ МИРЭА - Российский технологический университет, Россия, Москва \\ (c) 2021 Распопова Екатерина Владимировна \\ аспирант кафедры прикладного права \\ МИРЭА - Российский технологический университет, Россия, Москва \\ (c) 2021 Шевченко Герман Андреевич \\ аспирант кафедры прикладного права \\ МИРЭА - Российский технологический университет, Россия, Москва \\ (C) 2021 Лим А.А. \\ студент кафедры цифровых и аддитивных технологий \\ МИРЭА - Российский технологический университет, Россия, Москва
}

Предметом настоящей статьи выступает исследование возможностей создания и внедрения инновационных проектов в сфере высшего образования, касающихся молодежного технологического предпринимательства; опыт подобных коллабораций в рамках научно-технологического развития страны; возможности повышения конкурентоспособности российских университетов и экспорта российского образования. Тема статьи отражает описание условий поддержки инновационных проектов технологического предпринимательства как инструмента взаимодействия государства и университетов с целью стратегического и социально-экономического развития государства. Целью настоящей статьи является представление форм участия студенческих и иных технологических междисциплинарных стартапов как драйверов научно-технологического развития, места и роли государства в этом процессе. Методологию данной работы составили сравнительный, формально-юридический, аналитический методы. Результаты работы - это формулирование роли поддержки технологических стартапов. Область применения результатов работы включает в себя исследование государственной политики стратегического планирования в сфере научно-технологического развития.

Ключевые слова: технологический стартап, междисциплинарные научные исследования, поддержка технологического предпринимательства, экспорт высшего образования, научно-технологическое развитие

\footnotetext{
* Исследование подготовлено в рамках гранта РФФИ 19-011-00959 «Моделирование экспорта высшего образования в рамках новых стратегий публичного управления в Российской Федерации» 2019-2021 г.г.
} 
Развитие междисциплинарных научных исследований является фундаментальным основанием научно-технологического развития любого государства. Коллаборация научной мысли формирует главные условия прогресса и соответственно прогнозирует необходимые результаты научной, производственно-технологической деятельности хозяйствующих субъектов, научнообразовательных консорциумов. В целях реализации стратегического планирования государственной политики междисциплинарные научные проекты представляют собой приоритетные и многообещающие форматы партнерского взаимодействия государственного и негосударственного секторов экономики.

Взаимосвязанные научным содержанием прогрессивные идеи опираются на инновационную составляющую, на совершенно новые форматы, которые только начинают проявляться в потребностях общества и государства. Именно, эти проявления научной мысли позволят развиваться общественно-государственному содержанию политических и экономических устремлений системы публичного управления.

Федеральный закон «О науке и государственной научно-технической политике» от 23 августа 1996 года в статье 16.1 закрепляет положение о том, что «государство оказывает поддержку инновационной деятельности в целях модернизации российской экономики, обеспечения конкурентоспособности отечественной продукции, улучшения качества жизни населения [1]». Законодательный акт предусматривает различные формы государственной поддержки, которые варьируются от предоставления льгот по уплате налогов, предоставления образовательных услуг до финансового обеспечения и поддержки экспорта [2]. Оказанием государственной поддержки занимается множество организаций, обладающих публично-правовым статусом и реализующих отдельные функции публичного управления.

Распоряжением Правительства РФ от 11 августа 2011 г. № 1393-р «Об учреждении автономной некоммерческой организации «Агентство стратегических инициатив по продвижению новых проектов» была создана некоммерческая организация для содействия развитию социальной и профессиональной мобильности молодых профессиональных кадров и коллективов в сфере среднего предпринимательства и социальной cфере [3].
Агентство стратегических инициатив изначально задумывалось как публичное образование, обеспечивающее поддержку и продвижение инновационных проектов в технологическом предпринимательстве. Оно обладает правомочиями по полноценной экспертизе нормативных правовых актов и выявлению в их содержании административных барьеров для осуществления предпринимательской, инновационной и инвестиционной деятельности. Кроме того, Агентство стратегических инициатив участвует в определении векторных социально значимых проектов, включая «развитие системы профессиональной аттестации работников и долгосрочной поддержки молодых профессионалов и их коллективов» [4].

Агентство стратегических инициатив совместно с федеральными министерствами организует и поддерживает проведение ряда значимых конкурсов и мероприятий, которые позволяют инициативным и талантливым участникам добиваться реализации их идей, получать новые компетенции и навыки, финансовую поддержку своих проектов и создавать технологические предприятия. Это: интенсив «Остров», интенсив «Архипелаг 2121», Точки кипения, Национальная технологическая инициатива, Университет 20.35 и другие.

Поделимся собственным опытом реализации междисциплинарных проектов в ФГБОУ ВО «МИРЭА - Российский технологический университет» и участия в проекте Агентства стратегических инициатив. Для создания междисциплинарного технологического стартапа была организована проектная команда, состоящая из представителей кафедры прикладного права в Институте технологий управления и кафедры цифровых и аддитивных технологий в Физикотехнологическом институте. Результатом данной коллаборации, действующей в рамках развития новых рынков НТИ (EduNet, GameNet), был создан проект VR-платформы «Право \&VR». Проект «VR-платформа» заняла 25 место среди более 1000 команд проектов технологического предпринимательства в предакселераторе Архипелага 2121 (команда под номером 581 - Рис.1).

Проект предлагает:

1) разработку VR-контента, включающего в себя образовательный контент, включая проверочные задания, в том числе интерактивные, по различным отраслям права; 


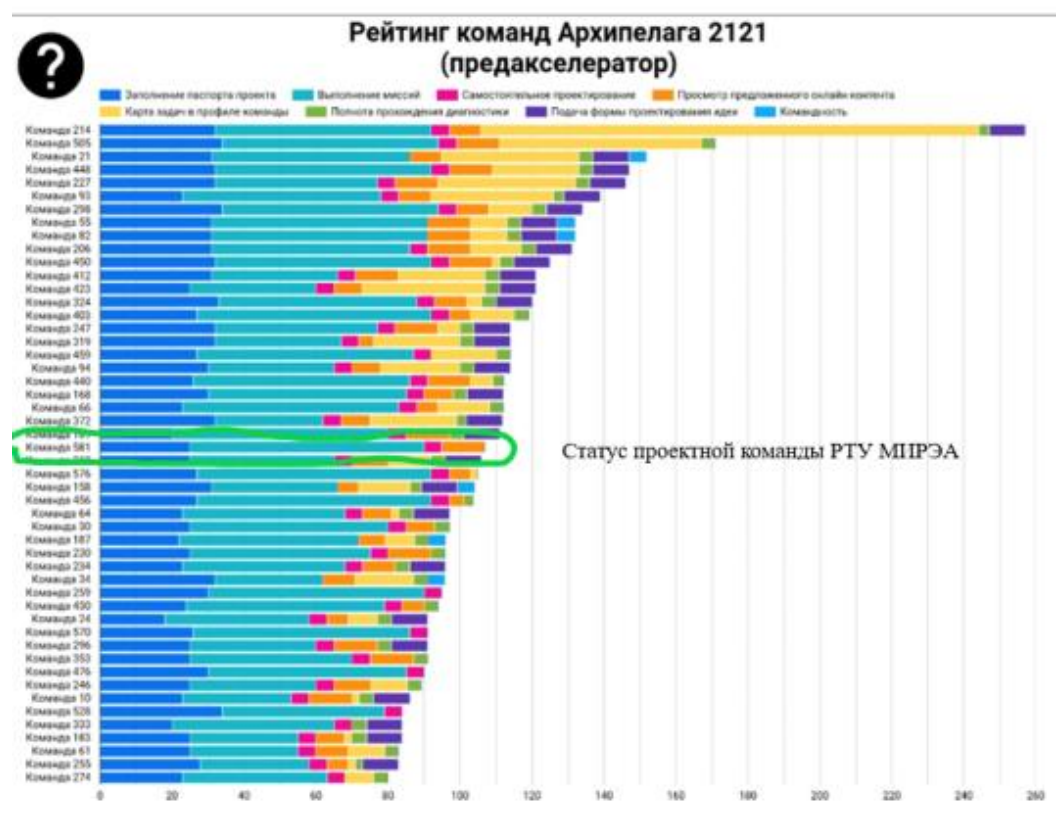

Puc. 1. Статус проектной команды (581) в последний день Предакселератора (25 место)

2) использование на VR-платформе чат-бота;

3) моделирование виртуального обучающего пространства;

4) функционирование мини-акселератора социально-правовых проектов;

5) размещение полезной правовой информации в вопросах и ответах.

По итоговому рейтингу VR-платформа «Право \&VR» заняла 40 место и вошла в ТОП-100 команд Акселератора Архипелага 2121.

На Интенсиве Архипелага 2121 проектная команда прошла обучение и несколько онлайн питчей (собеседований):

1) по защите проекта перед потенциальными инвесторами;

2) по взаимодействию с индустриальными партнерами.

По итогам работы команды в Предакселераторе VR-платформу «Право \&VR» выбрали для участия в очной экспертной сессии «Образовательные движки: EduNet» в рамках очного трека «Рынки и проекты-маяки», а очное участие команды в работе Архипелага 2121 прошло с 1 по 5 августа 2021 года в Великом Новгороде. Программа поддержки участников Архипелага предполагала возможность представления заявки на финансовую поддержку проекта в Фонд содействия инновациям. Проектная команда по итогам работы Предакселератора подала заявку в Фонд содействия инновациям по программе Старт-1 в рамках проекта «Право \&VR». Формы реализации потенциала команд технологических стартапов были разнообразными, команда РТУ МИРЭА выбрала участие в Предакселераторе, Форсайте новых рынков НТИ, проектировании сквозных технологий [5].

Нужно отметить, что университеты формируют собственную поддержку технологических проектов. Перед участием в Интенсиве Архипелаг 2121 совместная проектная команда приняла участие как тьютор в грантовом конкурсе РТУ МИРЭА для студентов, аспирантов и молодых ученых. Курируемая молодежная команда студентов и аспирантов от двух институтов заявила междисциплинарный стартап.

В апреле 2021 года в восьмой раз стартовал Конкурс инноваций в образовании (КИвО), организованный НИУ «Высшая школа экономики» и Рыбаков Фондом при поддержке Агентства стратегических инициатив [6], где стартапам также была предоставлена возможность попробовать свои силы и получить гранты. Совместная проектная команда подала заявку на участие в качестве команды технологического стартапа РТУ МИРЭА на КиВО-2021, по итогам конкурса команде были выданы сертификаты участников и даны экспертные рекомендации.

Еще одним проектом команды кафедры прикладного права было осуществление тью- 
торства над молодежным междисциплинарным проектом MY VOICE (STUDY)» - программа для ЭВМ-онлайн симулятор электронного голосования на выборах. В результате опубликована научная статья по итогам молодежного стартапа [7].

По итогам участия в инициативах АСИ, институтов развития и ведущих университетов со- вместная проектная команда приобрела новые компетенции, стратегическое видение собственного технологического междисциплинарного проекта, его сильные стороны и возможности коммерциализации, а также опыт реального взаимодействия и формирования нового ландшафта научно-технологического развития страны.

\section{Библиографический список}

1. О науке и государственной научно-технической политике: Федеральный закон от 23 августа 1996 г. № $127-$ Ф3 (с изм. и доп. от 2 июля 2021 г.) // Собр. законодательства Рос. Федерации. 1996. № 35. Ст. 4137; 2021 . № 27 (часть I). Ст. 5179.

2. Там же.

3. Об учреждении автономной некоммерческой организации «Агентство стратегических инициатив по продвижению новых проектов: Распоряжение Правительства РФ от 11 августа 2011 г. № 1393-р // Собр. законодательства Рос. Федерации. 2011. № 33. Ст. 4946.

4. Там же.

5. Архипелаг 2121: проектно-образовательный интенсив для индивидуальных участников, стартапов, регионов и вузов, которые развивают проекты в сфере новых технологий. Режим доступа. URL: https://a2121.ru/

6. Конкурс инноваций в образовании-2021. Режим доступа. URL: https://leader-id.ru/events/kivo2021

7. Шушпанов М.К., Макаров А. П., Саражинский Н. С., Коновалов Н. Н., Забайкалов А. П., Шукина Т. В. «МY VOICE (STUDY)» как программа для ЭВМ-онлайн симулятор электронного голосования на выборах: развитие НТИ и GameNet // Вопросы экономики и права. 2020. № 8 (146). С. 29-33 